DOI: $10.20472 / E S .2016 .5 .3 .004$

\title{
DOES GENDER DIVERSITY IN THE BOARDROOM INFLUENCE TOBIN'S Q OF CROATIAN LISTED FIRMS?
}

\author{
TOMISLAVA PAVIC KRAMARIC, TONI MILUN, IVAN PAVIC
}

\begin{abstract}
:
Gender diversity has attracted attention of scientists and practitioners of different fields. Despite the efforts and progress that has been made towards achieving gender equality in the workplace this has remained the weak point especially in the context of management and supervisory board positions. Therefore, the authors wanted to investigate whether this is true for Croatian listed companies. The hypotheses that women in leading positions has a positive impact on performance Croatian listed companies is tested using Tobin's Q indicator for the year 2014 whereas explanatory variables comprise different corporate governance variables such as Shannon index, Blau index, gender of the president of the management and supervisory board, share of women etc. The analysis is performed by using different empirical research methods including linear regression. The main findings are that women acting as the presidents of the management board positively influence performance. Moreover, having more women in the management board also has beneficial effects on financial success of the firm.
\end{abstract}

\section{Keywords:}

Corporate Finance, Corporate Governance, Firm Profit, Gender, Inequality

JEL Classification: G30, J10, L25

\section{Authors:}

TOMISLAVA PAVIC KRAMARIC, University of Split - University Department for Professional Studies, Croatia, Email: tpavic@oss.unist.hr TONI MILUN, Algebra University College, Croatia, Email: toni@tonimilun.com IVAN PAVIC, University of Split - Faculty of Economics, Croatia, Email: pavic@efst.hr

\section{Citation:}

TOMISLAVA PAVIC KRAMARIC, TONI MILUN, IVAN PAVIC (2016). Does gender diversity in the boardroom influence Tobin's Q of Croatian listed firms?. International Journal of Economic Sciences, Vol. V(3), pp. 50-65., 10.20472/ES.2016.5.3.004

Acknowledgment: This work has been fully supported by Croatian Science Foundation under the project UIP-2014-09-1745. Any opinions, findings, and conclusions or recommendations expressed in this material are those of the authors and do not necessarily reflect the views of Croatian Science Foundation. 


\section{Introduction}

Promoting gender equality in the work place as well as enhancing women's participation in leading positions within corporations has become an issue of global concern.

Equality between women and men is one of the European Union's founding values. It goes back to 1957 when the principle of equal pay for equal work became part of the Treaty of Rome. The Strategic engagement for gender equality 2016-2019 sets the framework for the European Commission's future work towards improving gender equality. One of its priority areas is promoting equality between women and men in decision-making positions since in October 2015, women accounted for just $22.7 \%$ of board members of the largest publicly listed companies registered in the EU countries (European Commission, Gender balance in decision-making positions).

Despite the numerous efforts that have been undertaken in order to achieve gender equality in the workplace, the results of academic research are unclear. Specifically, studying the results of scientific analysis in this field, one cannot notice a clear pattern in the influence of proportion of women in leadership positions within the company on the financial success of the company.

Therefore, the authors wanted to produce new academic knowledge on gender diversity in companies' top positions and its impact on firm performance.

While our general research question is similar to that of Lolic Cipcic and Pavic Kramaric (2016), this paper extends the previous mentioned one in a way that it investigates the influence of gender diversity in the boardroom on firm performance using a different methodological and analytical approach. Specifically, the paper by the latter authors focuses solely on financial institutions, while we add to the literature in a way that our research covers all companies listed on Zagreb Stock Exchange (ZSE) allowing the authors to measure the performance by Tobin's $Q$. Moreover, variables used in this research extend those applied in the above-mentioned paper.

All variables used in the analysis were calculated using data from companies' annual reports obtained from Zagreb Stock Exchange (ZSE) web-pages.

The rest of the paper is organized as follows: second part of the paper deals with previous research. The following section describes construction of the sample covered by the analysis. Description and calculation of variables is given in fourth section. Empirical part follows afterwards. After explaining methodology employed in the research, implications of the main findings are given in the sixth section. The paper finishes with concluding remarks. 


\section{Literature Review}

There is a vast body of literature investigating influence of gender diversity on corporate performance. The most distinguished characteristic between them is which performance measure is being used, i.e. whether the authors have used the objective, accounting measure of performance (e.g. ROA and ROE) or stock-based such as Tobin's $Q$. Furthermore, there are papers proving that women on the boards play an important and positive role with regard to financial performance, whereas there are papers proving the opposite. Taking into account these characteristics, the selection of papers on this topic is presented in the text following below.

Carter, Simkins and Simpson (2003) examine the relationship between board diversity, including gender diversity, and firm value for publicly traded Fortune 1000 firms in 1997. They control for possible endogeneity between firm value measured by Tobin's $Q$ and diversity using two-stage least squares analysis. After controlling for size, industry, and other corporate governance measures, the authors find significant positive relationships between the fraction of women on the board and firm value.

The objective of the article by Campbell and Mínguez-Vera (2008) is to examine the impact on firm performance of the presence of women on the boards of directors in Spain. The authors investigate the topic using panel data analysis on the sample of 68 non-financial firms listed on the continuous market in Madrid during the 1995-2000 period. Their finding is that greater gender diversity may generate economic gains, i. e. they find that the ratio of women to men on the board and diversity indices have a positive influence on firm value.

Joecks, Pull and Vetter (2012), on a panel data set of 151 listed German firms for the years 2000-2005, tried to explore whether the link between gender diversity and firm performance in terms of return on equity (ROE) follows a U-shape. The main finding is that the performance of a more diverse board exceeds the one of a male board. The authors have gone even further trying to find a certain threshold or "critical mass" of women on board to be associated with higher firm performance. The authors find that the critical percentage of about 30 percent women on the board, translating into an absolute critical mass of on average three women, significantly increases ROE as compared to having only one woman on the board.

Adams and Ferreira (2009) study deals with women in the boardroom and their impact on governance and performance using the sample that consisted of an unbalanced panel of 86,714 director level observations from 1,939 US firms for the period 19962003. When examining the influence of gender diversity, the authors use two measures of performance: Tobin's q and ROA. The results for Tobin's q suggest that the coefficient on diversity is positive and significant at the $10 \%$ level. However, in order to address omitted variables problems, authors added firm fixed effect, after which the coefficient on diversity remained statistically significant at the $10 \%$ level, but with negative sign. 
Similar results are also obtained when using ROA variable as performance measure. At the end, the authors note that although a positive relation between gender diversity in the boardroom and firm performance is often cited in the popular press, it is not robust to any of their methods of addressing the endogeneity of gender diversity.

Haslam et al. (2010) examined FTSE 100 companies in the period 2001-2005, focusing on the relationship between the presence of women on company boards and both accountancy-based and stock-based measures of company performance. The database included data from 126 companies that were included in the FTSE 100 index in at least one of the five years in which authors were interested, while the analysis is conducted using ANOVA. Their findings indicate that this relationship between gender diversity and performance varies as a function of the particular measure of performance one employs. Specifically, the analysis reveals that there was no relationship between women's presence on boards and accountancy-based measures of performance (ROA, $\mathrm{ROE})$. However, consistent with 'glass cliff' research there was a negative relationship between women's presence on boards and stock-based measures of performance (Tobin's Q).

Pathan and Faff (2013) study whether board structure, including board size, independence and gender diversity, relates to performance using a broad panel of large US banks over the period 1997-2011. The analysis is conducted employing several performance measures including both accounting and stock-based measures using the two-step GMM approach. The results suggest that gender diversity improves bank performance but only in the pre-Sarbanes Oxley Act period (1997-2002), but it weakens it otherwise.

Ahern and Dittmar (2012) analysed the sample of Norwegian firms after a quota constraint has been imposed requiring that $40 \%$ of Norwegian firms' directors be women. In order to estimate the impact of the quota on firm value, the authors use the pre-quota cross-sectional variation in female board representation as an exogenous instrument for the variation in board changes mandated by the quota. In a panel of 248 publicly listed Norwegian firms from 2001 to 2009, they find a large negative impact of the mandated board changes on firm value. Moreover, the announcement of the quota caused a large decline in Tobin's $Q$ over the following years. The quota also led to deterioration in operating performance.

Moreover, it is worth mentioning that a meta analyis on female representation on corporate boards and firm financial performance by Pletzer, Nikolova, Kedzior and Voelpel (2015) based on data from 20 studies, suggests that the relationship between the percentage of female directors on corporate boards and firm financial performance is consistently small and non-significant. 


\section{Data Sampling}

The authors' intention was to cover by the analysis all 146 companies listed on the regulated market of the Zagreb Stock Exchange (ZSE) in 2014. However, only a fraction of these companies' shares was traded with on December $31^{\text {st }} 2014$. Therefore, our sample needed to be reduced to 43 companies and it consists of all companies whose shares were listed and traded with on the ZSE on December $31^{\text {st }} 2014$. The data refer to regulated market trading data including both official and regular market. After adjusting for incomplete data, the final sample was reduced furthermore to 36 companies. These companies belong to different sectors including:

- Manufacture of transport equipment,

- Legal, accounting, management, architecture, engineering, technical testing and analysis activities,

- Accommodation and food service activities,

- Wholesale and retail trade; repair of motor vehicles and motorcycles,

- Agriculture, forestry and fishing,

- Financial and insurance activities,

- Manufacture of food products, beverages and tobacco products,

- Manufacture of computer, electronic and optical products,

- Other manufacturing, and repair and installation of machinery and equipment,

- Telecommunications,

- Manufacture of basic pharmaceutical products and pharmaceutical preparations,

- Manufacture of chemicals and chemical products,

- Construction,

- Transportation and storage and

- Manufacture of textiles, apparel, leather and related products.

\section{Description of Variables}

\section{Dependent variable}

Since our data sample comprises the companies listed on Zagreb Stock Exchange (ZSE), the authors opted for stock-based measure of company performance, an approach applied by Carter, Simkins and Simpson (2003), Campbell and Mínguez-Vera (2008), Haslam et al. (2010), Ahern and Dittmar (2012) etc. Therefore, firm performance is measured by Tobin's $Q$.

Specifically, we use Tobin's $Q$ as a measure of firm performance in our study rather than accounting-based measures because, as stated by Campbell and Mínguez-Vera (2008) citing Montgomery and Wernerfelt (1988), it reflects the market's expectations of future earnings and is thus a good proxy for a firm's competitive advantage.

Originally, for the calculation of Tobin's Q, Tobin (1969) states that the numerator, is the market valuation: the going price in the market for exchanging existing assets. The 
other, the denominator, is the replacement or reproduction cost: the price in the market for the newly produced commodities.

However, as a measure of firm value we use an approximation of Tobin's Q (TQ), defined as the sum of the market value of shares and the book value of debt divided by the book value of total assets with market value of shares being calculated as share price as at $31^{\text {st }}$ December 2014 multiplied by number of shares, i.e.:

Tobin's $Q=\frac{\text { market value of shares }+ \text { book value of debt }}{\text { book value of assets }}$

Dependent variable Tobin's Q (TQ) was tested for normality. Kolmogorov- Smirnov test (Kolmogorov, 1933), (Smirnov, 1948) and Shapiro-Wilk's test (Shapiro and Wilk, 1965) were used. Since the variable TQ did not meet the normality assumption $(p<0.05)$, the data have been transformed using the logarithm function. Natural logarithm of Tobin's $Q$ (LN_TQ) is well modelled by a normal distribution ( $p>0.05)$.

Table 1: Normality tests

\begin{tabular}{|l|l|l|}
\hline Variable & Kolmogorov-Smirnov & Shapiro-Wilk \\
\hline Tobin's Q & 0.047 & $<0.001$ \\
\hline In (Tobin's Q) & 0.200 & 0.136 \\
\hline
\end{tabular}

Source: authors' calculation

\section{Explanatory variables}

Gender of the president of the management board (MB_P) and supervisory board (SB_P) is included in the model as dummy variable with 0 representing male president and 1 female.

Share of women in the management board (MB_SW) and supervisory board (SB_SW) is calculated as the number of board female members divided by the total number of board members.

Dummy variable regarding gender composition of the management board (MB_D) and supervisory board (SB_D) reaches value 0 in companies with no women on the board and 1 if there is at least one female member.

Despite the ambiguous findings of the previous research, we expect the variables gender of the president of the management (MB_P) and supervisory board (SB_P), share of women in the management (MB_SW) and supervisory board (SB_SW) as well as dummy variable regarding gender composition of the management board (MB_D) and supervisory board (SB_D), to have a positive effect on Tobin's Q. Specifically, as stated by Schrader, Blackburn and lles (1997), firms employing more women managers have probably done a better job of recruiting capable managers from the total available talent pool, and consequently will be in a better position to link with customers, 
employees, and other constituencies. Moreover, firms employing higher percentages of women are likely to perform better inasmuch as they are more progressive and more competitive because their management contingents more closely mirror the composition of existing market.

Diversity as variety conceptualizes categorical differences across the relevant characteristics between group members with variety being commonly measured by both Blau's index and the Shannon-Wiener entropy (Solanas, Selvan, Navarro and Leiva, 2012). Therefore, the authors applied this concept in order to measure diversity of the management and supervisory board.

Blau index, also known as Simpson index, measuring gender diversity on the management board (MB_BL) and supervisory board (SB_BL), take into account the number of gender categories (two) as well as the evenness of the distribution of board members among them. It is measured as:

$$
1-\sum_{i=1}^{n} p_{i}^{2}
$$

where $p_{i}$ is the percentage of board members in each category (men and women) and $n$ is the total number of board members. Values of the Blau index for gender diversity range from 0 to a maximum of 0.5 , which occurs when the board comprises an equal number of men and women (Campbell and Mínguez-Vera, 2008).

Shannon index, or Shannon-Wiener entropy, measures gender diversity on the management board (MB_SH) and supervisory board (SB_SH) as well. It is calculated as:

$-\sum_{i=1}^{n} p_{i} \ln p_{i}$

where $p_{i}$ is the percentage of board members in each category (men and women) and $n$ is the total number of board members. The minimum value of Shannon index is zero and diversity is maximised when both genders are present in equal proportions, when Shannon index amounts to 0.69. Being a logarithmic measure of diversity it is more sensitive to differences in small relative abundances (Baumgartner, 2006).

The authors also predict that these diversity measures will positively influence performance. This assumption is built upon lles and Auluck (1993) who found that diverse work forces were beneficial to firms because they facilitated team problem solving and synergy. Furthermore, the ability to manage diversity fostered the incorporation of various perspectives into organizational decision-making, and firms that united a wider range of participants performed well. 
Moreover, for the purpose of statistical analysis four control variables were included in the model. These comprise size of the company based on both number of employees and assets, leverage and age of the company.

Size of the company based on number of employees (EMP) is calculated as a natural logarithm of total number of employees. Moreover, the authors also used the variable size of the company measured as a natural logarithm of total assets (AS). Size variable, measured by both number of employees and assets, is expected to positively influence performance since the conventional wisdom is that, as stated by Lee (2009), larger firms tend to be more profitable than their smaller counterparts, either due to efficiency gains or higher market power.

Furthermore, leverage variable (LEV) was calculated as book value of debt to book value of total assets showing a level of the company's asset that is financed from external debt sources. Academic literature provides ambiguous influence of this variable on performance. Based on the agency cost theory, financial leverage can positively influence firm performance because leverage can be treated as a tool for disciplining management. However, as stated by llyukhin (2015), high indebtedness may lead to significant financial limitations and that influences firm performance negatively.

The age of a company (AGE) as a control variable was calculated as the current year of the analysis reduced by foundation year of the company. The expected effect of company's age on performance is ambiguous. For example, Coad, Segada and Terruel (2010) support evidence that firms improve with age, finding that ageing firms experience rising levels of productivity, profits, larger size, lower debt ratios, and higher equity ratios. But, they also find that older firms have lower expected growth rates of sales, profits and productivity, they have lower profitability levels (when other variables are controlled for), and also that they appear to be less capable to convert employment growth into growth of sales, profits and productivity.

Descriptive statistics of dependant and explanatory variables used in the analysis are given in table 2 .

Table 2: Descriptive statistics of variables in model

\begin{tabular}{|l|l|r|r|r|r|}
\hline Variable & $\begin{array}{l}\text { Variable } \\
\text { abbreviation }\end{array}$ & \multicolumn{1}{l|}{ Mean } & $\begin{array}{l}\text { Standard } \\
\text { deviation }\end{array}$ & Min & Max \\
\hline In (Tobin's Q) & Ln_TQ & -0.1533 & 0.3910 & -1.26 & 1.03 \\
\hline MB gender of president & MB_P & 0.1389 & 0.3507 & 0 & 1 \\
\hline MB share of women & MB_SW & 0.1392 & 0.2307 & 0 & 1 \\
\hline MB female members, dummy & MB_D & 0.3611 & 0.4871 & 0 & 1 \\
\hline MB Blau index & MB_BL & 0.1361 & 0.2029 & 0 & 0.5 \\
\hline MB Shannon index & MB_SH & 0.1981 & 0.2906 & 0 & 0.69 \\
\hline SB gender of president & SB_P & 0.1111 & 0.3187 & 0 & 1 \\
\hline SB share of women & SB_SW & 0.2181 & 0.1759 & 0 & 0.67 \\
\hline SB female members, dummy & SB_D & 0.7222 & 0.4543 & 0 & 1 \\
\hline SB Blau index & SB_BL & 0.2809 & 0.1778 & 0 & 0.50 \\
\hline SB Shannon index & SB_SH & 0.4192 & 0.2567 & 0 & 0.69 \\
\hline
\end{tabular}

Source: authors' calculation 
Gender structure of management board is as follows: women are acting as presidents of management board in 5 out of 36 companies (13.89\%). The share of women in management board amounts to $13.92 \%$. Only $36.11 \%$ companies have at least one woman as a member of management board, while $63.89 \%$ of companies have only male members of $\mathrm{MB}$.

The share of women on supervisory boards is higher than on management boards. Specifically, $21.81 \%$ members are women and $72.22 \%$ of all supervisory boards have at least one woman. Women are underrepresent as presidents of supervisory boards with only four women (11.11\%) acting as presidents.

Descriptive statistics of control variables are given in table 3.

Table 3: Descriptive statistics of control variables

\begin{tabular}{|l|l|r|r|r|r|}
\hline Variable & $\begin{array}{l}\text { Variable } \\
\text { abbreviation }\end{array}$ & \multicolumn{1}{l|}{ Mean } & $\begin{array}{l}\text { Standard } \\
\text { deviation }\end{array}$ & \multicolumn{1}{l|}{ Min } & \multicolumn{1}{l|}{ Max } \\
\hline Ln (number of employees) & EMP & 6,1136 & 1,5603 & 1,95 & 8,58 \\
\hline Ln (assets) & AS & 20,7621 & 1,4611 & 16,82 & 25,01 \\
\hline Leverage & LEV & 0,4750 & 0,2668 & 0,00 & 0,99 \\
\hline Age & AGE & 62,2857 & 37,8305 & 10 & 186 \\
\hline
\end{tabular}

Source: authors' calculation

\section{Methodology and Empirical Research}

The multiple regression model was used to examine the influence of gender diversity and other variables on Tobin's $Q$. The correlation matrix, tolerance and variance inflation factors (VIF) were used to test the presence of multicollinearity. Moreover, BreuschPagan test was used to evaluate homoscedasticity.

The following models were estimated:

$$
\begin{aligned}
& y=\beta_{0}+\beta_{1} \cdot E M P+\beta_{2} \cdot A S+\beta_{1} \cdot L E V+\beta_{4} \cdot A G E+\beta_{5} \cdot M B \_P+\beta_{6} \cdot S B \_P \\
& y=\beta_{0}+\beta_{1} \cdot E M P+\beta_{2} \cdot A S+\beta_{1} \cdot L E V+\beta_{4} \cdot A G E+\beta_{5} \cdot M B \_S W+\beta_{6} \cdot S B \_S W \\
& y=\beta_{0}+\beta_{1} \cdot E M P+\beta_{2} \cdot A S+\beta_{1} \cdot L E V+\beta_{4} \cdot A G E+\beta_{5} \cdot M B \_D+\beta_{6} \cdot S B_{-} D \\
& y=\beta_{0}+\beta_{1} \cdot E M P+\beta_{2} \cdot A S+\beta_{1} \cdot L E V+\beta_{4} \cdot A G E+\beta_{5} \cdot M B \_B L+\beta_{6} \cdot S B \_B L \\
& y=\beta_{0}+\beta_{1} \cdot E M P+\beta_{2} \cdot A S+\beta_{1} \cdot L E V+\beta_{4} \cdot A G E+\beta_{5} \cdot M B \_S H+\beta_{6} \cdot S B \_S H
\end{aligned}
$$

Since the objective of this paper is to examine the influence of gender diversity on management or supervisory boards on company's performance in Croatia, these five models were tested.

Model 1 is estimated with the equation (4), i.e.:

$y=\beta_{0}+\beta_{1} \cdot E M P+\beta_{2} \cdot A S+\beta_{1} \cdot L E V+\beta_{4} \cdot A G E+\beta_{5} \cdot M B_{-} P+\beta_{6} \cdot S B_{-} P$

Test for multicollinearity is the first test that was taken. The correlation coefficients (Pearson, 1895) between the selected variables are shown in a table below. 
Table 4: Correlation matrix

\begin{tabular}{|l|c|c|c|c|c|c|c|}
\hline & LN_TQ & EMP & AS & LEV & AGE & MB_P & SB_P \\
\hline LN_TQ & & & & & & & \\
\hline EMP & $0.422^{\star *}$ & & & & & & \\
\hline AS & 0.169 & $0.573^{\star *}$ & & & & & \\
\hline LEV & 0.275 & 0.141 & 0.114 & & & & \\
\hline AGE & -0.070 & -0.089 & -0.206 & 0.082 & & & \\
\hline MB_P & 0.218 & -0.240 & $-0.297^{\star}$ & 0.077 & -0.077 & & \\
\hline SB_P & -0.005 & -0.053 & 0.091 & -0.053 & -0.077 & -0.142 & \\
\hline
\end{tabular}

Source: authors' calculation

*statistically significant at 0.05

** statistically significant at 0.01

The correlation coefficients among pairs of predictor variables are not high; since all coefficients are lower than 0.8 . Stepwise method was used to determine which variables are statistically significant in the model. Only two of them entered the model: gender of president of management board (MB_P) with $p$ value equalling 0.032 and size of the company measured as a natural logarithm of employees (EMP) with $p$ value equalling 0.002 .

$y=-0.977+0.126 \cdot E M P+0.378 \cdot M B_{-} P$

Table 5: Variables in Model 1

\begin{tabular}{|l|c|c|c|c|}
\hline & Coefficient & p-values & Tolerance & VIF \\
\hline Constant & -0.977 & $<0.001$ & & \\
\hline EMP & 0.126 & 0.002 & 0.942 & 1.061 \\
\hline MB_P & 0.378 & 0.032 & 0.942 & 1.061 \\
\hline
\end{tabular}

Source: authors' calculation

Coefficients in table 5 show that companies with a woman acting as a president of management board have higher Tobin's $Q$ values than companies with a male president. Furthermore, larger companies in terms of number of employees have higher value of Tobin's $Q$ as well. Variable SB_P (gender of the president of the supervisory board) was excluded from the model with $\mathrm{p}=0.335$. High value of tolerance (more then 0.2 ) and low value of VIF - variance inflation factors (less than 5) contributed in rejecting the hypothesis of multicollinearity (Freund, Littell and Creighton, 2003).

Table 6: Model 1 statistics

\begin{tabular}{|l|l|}
\hline $\mathrm{R}^{\wedge} 2$ & 0.286 \\
\hline $\mathrm{F}$ & 6.618 \\
\hline $\mathrm{p}$-value & 0.004 \\
\hline Breusch-Pagan sig. & 0.604 \\
\hline
\end{tabular}

Source: authors' calculation

Model 1 is statistically significant with high $F=6.618(>2.48)$ and with low $p$ value equalling $0.004 \quad(<0.05)$. Breusch-Pagan test was used to test homoscedasticity 
(Breusch and Pagan, 1979). Since p value equals 0.604, the null hypothesis of homoscedasticity cannot be rejected.

Since two dummy variables (MB_P and SB_P) were used in model, $\mathrm{R}$-squared is low $\left(R^{\wedge} 2=0.286\right)$, which indicates wide prediction interval. $28.6 \%$ of the variance in the response variable can be explained by the explanatory variables. However, low pvalues still imply real relationship between predictors and response variable.

Model 2 is estimated with the equation (5), i.e.:

$y=\beta_{0}+\beta_{1} \cdot E M P+\beta_{2} \cdot A S+\beta_{1} \cdot L E V+\beta_{4} \cdot A G E+\beta_{5} \cdot M B_{-} S W+\beta_{6} \cdot S B \_S W$

The second model has two new variables: share of women on the management board (MB_SW) and share of women on the supervisory board (SB_SW).

Table 7: Correlation matrix

\begin{tabular}{|l|c|c|c|c|c|c|c|}
\hline & LN_TQ & EMP & AS & LEV & AGE & MB_SW & SB_SW \\
\hline LN_TQ & & & & & & & \\
\hline EMP & $0.422^{* *}$ & & & & & & \\
\hline AS & 0.169 & $0.573^{\star *}$ & & & & & \\
\hline LEV & 0.275 & 0.141 & 0.114 & & & & \\
\hline AGE & -0.070 & -0.089 & -0.206 & 0.082 & & & \\
\hline MB_SW & $0.398^{* *}$ & 0.106 & -0.067 & 0.110 & -0.122 & & \\
\hline SB_SW & -0.003 & -0.246 & 0.005 & 0.075 & -0.254 & 0.044 & \\
\hline
\end{tabular}

Source: authors' calculation

** statistically significant at 0.01

Correlation matrix (Pearson, 1895), shown in Table 7, as well as VIF and tolerance values, shown in table 8 , indicate the absence of multicollinearity. However, only two variables are statistically significant. Specifically, variables share of women in management board (MB_SW) with $\mathrm{p}=0.020$ and size of the company measured by number of employees (EMP) with $p=0.013$ entered the model.

$y=-0,826+0,096 \cdot E M P+0,605 \cdot M B \_S W$

Table 8: Variables in Model 2

\begin{tabular}{|l|c|c|c|c|}
\hline & Coefficient & p-values & Tolerance & VIF \\
\hline Constant & -0.826 & 0.001 & & \\
\hline EMP & 0.096 & 0.013 & 0.989 & 1.011 \\
\hline MB_SW & 0.605 & 0.020 & 0.989 & 1.011 \\
\hline
\end{tabular}

Source: authors' calculation

Coefficients of variables in Model 2, presented in table 8, indicate that companies with more female members on management board have a higher Tobin's $Q$. As proved by the Model 1, larger companies in terms of number of employees also have higher value 
of Tobin's Q. Moreover, high value of tolerance (more then 0.2) and low value of VIF variance inflation factors (less than 5) contributed in rejecting the hypothesis of multicollinearity (Freund, Littell and Creighton, 2003).

Furthermore, variable SB_SW (share of women on the supervisory board) was excluded from model since $p$ value equalled 0.514 .

Table 9: Model 2 statistics

\begin{tabular}{|l|l|}
\hline$R^{\wedge} 2$ & 0.304 \\
\hline$F$ & 7.204 \\
\hline$p$-value & 0.003 \\
\hline Breusch-Pagan sig. & 0.079 \\
\hline
\end{tabular}

Source: authors' calculation

As shown by table 9 , Model 2 is statistically significant with $p$ value equal to 0.003 . Moreover, Breusch-Pagan test was used to test homoscedasticity (Breusch and Pagan, 1979). Since $p$ value equals 0.079 , the null hypothesis of homoscedasticity cannot be rejected.

$\mathrm{R}^{\wedge} 2$ equals 0.304 and it is slightly higher than in Model 1 , but is still pretty low. It indicates high variability of data, i.e. it can suggest that some other variables, not included in model, could have important influence on dependant variable. However, since $p$-value is low, it implies that predictor variables still provide information about response variable.

The remaining variables on corporate governance including dummy variable whether there is at least one or no women at all on the board, Blau index as well as Shannon index are included in other three models. However, since the $p$ values of these variables exceeded 0.05 , i.e. they proved to be statistically insignificant, they were not included in the model. The coefficients of these variables are presented in tables 10 through 12 .

Table 10: Variables in Model 3

\begin{tabular}{|l|l|l|}
\hline Model 3 & Coefficients & p-values \\
\hline MB_D & 0.105 & 0.515 \\
\hline SB_D & 0.095 & 0.554 \\
\hline
\end{tabular}

Source: authors' calculation

Table 11: Variables in Model 4

\begin{tabular}{|l|l|l|}
\hline Model 4 & Coefficients & p-values \\
\hline MB_BL & 0.015 & 0.925 \\
\hline SB_BL & 0.094 & 0.573 \\
\hline
\end{tabular}

Source: authors' calculation 
Table 12: Variables in Model 3

\begin{tabular}{|l|l|l|}
\hline Model 5 & Coefficients & p-values \\
\hline MB_SH & -0.001 & 0.995 \\
\hline SB_SH & 0.093 & 0.098 \\
\hline
\end{tabular}

Source: authors' calculation

In all models, the only statistically significant variable was size of the company measured as a natural logarithm of number of employees.

\section{Discussion of Results from an Economic View}

Gender diversity is one of the most significant governance issues. Therefore, the central question of our analysis is the impact board diversity would have on corporate performance. Moreover, as suggested by Campbell and Mínguez-Vera (2008), it also has implications on female participation in economic activity and in society in general.

The findings of our study support the notion that board structure is an important determinant of company performance, since gender of the president of the management board as well as the share of women on the management board statistically significantly and positively influences performance.

These findings support the view that gender diversity in the boardroom actually enhances shareholder value suggesting that boards that are more diverse are not merely right thing to do, i.e. we provide for good economic arguments for increasing the diversity of boards. Specifically, the empirical results support the resource-based theory of competitive advantage suggesting the view that human capital resources are key to competitive advantage (Barney, 1991).

Carter, Simkins and Simpson (2003), citing Robinson and Dechant (1997) state that corporate diversity promotes a better understanding of the marketplace. Because demographic projections indicate the marketplace is becoming more diverse, matching the diversity of a company to the diversity of the company's potential customers and suppliers increases the ability to penetrate markets. Moreover, diversity increases creativity and innovation, produces more effective problem solving and enhances the effectiveness of corporate leadership.

The positive relationship between gender diversity in the boardroom and corporate performance can also be explained by Shrader, Blackburn and Illes (1997) citing Rosener (1995). They state that women have extraordinary managerial skills in a way that they are good at seeing the big picture issues and can have a strong impact as top managers on productivity, morale and profit.

It is also worth citing Galinsky et al. (2015) that diversity, including heterogeneity in gender has material benefits for organizations. 
Regarding the control variables that were employed in the analysis, variable size based on the number of employees proved to positively influence corporate performance in both statistically significant models.

To sum it up, the empirical findings suggest that board diversity should not only be considered in terms of ethical considerations since we have found economic evidence that lies behind the intuitive belief in a positive relationship between gender diversity and firm performance. Therefore, the positive discrimination in favour of female boardroom should become a key feature of the corporate governance in Croatia.

\section{Conclusion}

There is generally accepted view of women being under-represented in leadership positions in corporations. Therefore, numerous institutions from OECD through European Commission to governmental institutions of a specific country are working towards promoting better gender equality.

Although, sometimes, scientific research does not provide a basis for the continuation of these activities, the results of our survey support increased gender equality in the boardroom.

The main findings suggest that gender diversity is crucial for financial performance of Croatian listed firms. Specifically, gender of the president of the management board positively influences firm performance measured by Tobin's $Q$ but results also suggest that higher the proportion of women as members of the management board the better the performance.

The findings speak in favour of the thesis of enhancing women's integration in the top positions allowing the conclusion that gender diversity should not only be promoted for ethical reasons to promote fairness as suggested by Pletzer, Nikolova, Kedzior and Voelpel (2015). Or, as stated by Adams and Ferreira (2009), our results suggest that female directors are not mere tokens, but they add value by bringing new ideas and different perspectives to the table.

However, regarding the implications of the results of the analysis, one should take into account the modest sample of the companies being analysed. Specifically, authors recognize that future research might consider increasing time span of the analysis as well as introducing some new controls that might be behind the positive empirical association between board gender diversity and the performance measure used. 


\section{References}

ADAMS, R. B. and FERREIRA, D. (2009) Women in the boardroom and their impact on governance and performance, Journal of Financial Economics. 2009, Vol. 94, No. 2, p. 291-309.

AHERN, K. R. and DITTMAR, A. K. (2012) The Changing of the Boards: The Impact on Firm Valuation of Mandated Female Board Representation, Quarterly Journal of Economics. 2012, Vol. 127, No. 1, p. 137-197. http://papers.ssrn.com/sol3/papers.cfm?abstract id=1364470

BARNEY, J. (1991) Firm Resources and Sustained Competitive Advantage, Journal of Management. 1991, Vol. 17, p. 99-120.

BAUMGÄRTNER, S. (2006) Measuring the diversity of what? And for what purpose? A conceptual comparison of ecological and economic biodiversity indices, Working paper. 2006, http://papers.ssrn.com/sol3/papers.cfm?abstract id=894782

BREUSCH, T. S.; PAGAN, A. R. (1979) A Simple Test for Heteroskedasticity and Random Coefficient Variation, Econometrica. 1979, Vol. 47 No. 5, p. 1287-1294

CARTER, D. A. ; SIMKINS, B. J. and SIMPSON, W. G. (2003) Corporate Governance, Board Diversity, and Firm Value, The Financial Review. 2003, Vol. 38, No. 1, p. 33-35. https://www.researchgate.net/publication/4990531 Corporate Governance Board Diversity and Firm Value

CAMPBELL, K. and MíNGUEZ-VERA, A. (2008) Gender Diversity in the Boardroom and Firm Financial Performance, Journal of Business Ethics. 2008, Vol. 83, No. 3, p. 435-451.

COAD, A.; SEGADA, A. and TERRUEL, M. (2010) Like milk or wine: Does firm performance improve with age?, 2010, \#1006, p. 1-31.

European Commission, Strategic engagement for gender equality 2016-2019, http://ec.europa.eu/justice/gender-equality/document/files/strategic engagement en.pdf

FREUND, R. J.; LITTELL, R. C. and CREIGHTON, L. (2003) Regression Using JMP. Cary, NC: SAS Institute, Inc.

GALINSKY, A. D.; HOMAN, A. C.; PHILLIPS, K. W.; APFELBAUM, E. P.; SASAKI, S. J.; RICHESON, J. A.; OLAYON, J. B. and MADDUX, W. W. (2015) Maximizing the Gains and Minimizing the Pains of Diversity: A Policy Perspective, Perspectives on Psychological Science, 2015, Vol. 10, No. 6, p. $742-748$, http://pps.sagepub.com/content/10/6/742.full.pdf+html

HASLAM, S. A.; RYAN, M. K.; KULICH, C.; TROJANOWSKI, G. and ATKINS, C. (2010) Investing with Prejudice: The Relationship between Women's Presence on Company Boards and Objective and Subjective Measures of Company Performance, British Journal of Management. 2010, Vol. 21, No. 2, p. $484-497$

ILES, P. and AULUCK, R. (1993) Developing Managers and Organisations to Manage and Value Difference, 8th International Organisation Development Association World Congress, Cape Town, South Africa 
ILYUKHIN, E. (2015), The Impact of Financial Leverage on Firm Performance: Evidence from Russia, Journal of Corporate Finance Research, 2015, Vol. 34, No. 2, p. 24-36

JOECKS, J.; PULL, K. and VETTER, K (2013) Gender Diversity in the Boardroom and Firm Performance: What Exactly Constitutes a "Critical Mass?" Journal of Business Ethics. 2013, Vol. 118, No. 1, p. 61-72. http://papers.ssrn.com/sol3/papers.cfm?abstract id=2009234

KOLMOGOROV, A. (1933) Sulla determinazione empirica di una legge di distribuzione, Giornale dell'Istituto Italiano degli Attuari. 1933, Vol. 4, p. 83-91.

LEE, J. (2009) Does Size Matter in Firm Performance? Evidence from US Public Firms, International Journal of the Economics of Business. 2009, Vol 16, No. 2, p. 189-203

PATHAN, S. and FAFF, R. (2013) Does board structure in banks really affect their performance?, Journal of Banking \& Finance. 2013, Vol. 37, p. 1573-1589

PEARSON, K. (1895) Notes on regression and inheritance in the case of two parents, Proceedings of the Royal Society of London. 1895, 58, p. 240-242

PLETZER, J. L.; NIKOLOVA, R.; KEDZIOR, K. K. and VOELPEL, S. C. (2015) Does Gender Matter? Female Representation on Corporate Boards and Firm Financial Performance - A Meta-Analysis. PLOS ONE. 2015, Vol. 10, No. 6,

http://journals.plos.org/plosone/article?id=10.1371/journal.pone.0130005

SCHRADER, C. B.; BLACKBURN, V. B. and ILES, P. (1997) Women in Management and Firm Financial Performance: An Exploratory Study, Journal of Managerial Issues. 1997, Vol. 9, No.3, p. $355-372$

SHAPIRO, S. S. and WILK, M. B. (1965) An Analysis of Variance Test for Nomality, Biometrika. 1965, Vol. 52, p. 591-611.

SMIRNOV, N. (1948) Table for Estimating the Goodness of Fit of Empirical Distributions, The Annals of Mathematical Statistics. 1948, Vol. 19, p. 279-281.

SOLANAS, A.; SELVAN, R. M.; NAVARRO, J. and LEIVA, D. (2012) Some Common Indexes of Group Diversity: Upper Boundaries, Working paper. http://diposit.ub.edu/dspace/bitstream/2445/45784/1/623311.pdf also available at Proceedings of Measuring Behavior. 2012, Utrecht, The Netherlands, http://www.measuringbehavior.org/files/2012/ProceedingsPDF\%28website\%29/Posters/Solanas et al MB2012.pdf

TOBIN, J. (1969) A General Equilibrium Approach To Monetary Theory. Journal of Money, Credit and Banking. 1969, Vol. 1, No. 1, p. 15-29

Zagreb Stock Exchange, www.zse.hr 